\title{
Microscopic findings for the study of biofilms in food environments*
}

\author{
Magdalena A. Olszewska ${ }^{凶}$ \\ Chair of Industrial and Food Microbiology, Faculty of Food Science, University of Warmia and Mazury in Olsztyn, Olsztyn, Poland
}

\begin{abstract}
The capability of bacteria to colonize food processing surfaces and to form biofilm has become an emerging concern for food industry. The presence and persistence of biofilm on food processing surfaces may pose a risk of food spoilage or food poisoning. A better understanding of bacterial adhesion and resistance of biofilms is needed to ensure quality and safety of food products. This review focuses on microscopic approaches incorporated to explore biofilm mode of existence in food processing environments. An application of antimicrobial agents for the biofilm control, in particular for bacteria connected with food processing environments, is also highlighted. In addition, some aspects of biofilm resistance, especially the phenomenon of persister cells, are discussed.
\end{abstract}

Key words: biofilm, food industry, persister cells, microscopic approaches

Received: 31 October, 2013; revised: 10 December, 2013; accepted: 19 December, 2013; available on-line: 30 december, 2013

\section{INTRODUCTION}

Biofilm is a heterogeneous structure of microorganisms surrounded by the layer of microbial-originated extracellular polymeric substances (EPS) adhered to biological or abiotic surfaces (Kiskó \& Szabó-Szabó, 2011). A biofilm is characterized by a unique architecture and specific features of adhered cells, which are physiologically different from their planktonic counterparts (Kokare et al., 2009; Simões et al., 2010). Biofilms are very diverse and unique, not just to the microorganisms, but to the extracellular matrix, in which these microorganisms are enmeshed (Giaouris et al., 2012). Biofilm is referred to as a survival mechanism of different microorganisms formed in response to hostile conditions due to constant changes in the environment (Araújo et al., 2011). Food processing surfaces and equipment may be favourable environments for biofilm formation, particularly where moisture and nutrients are available (Myszka \& Czaczyk, 2011). Once a biofilm takes hold, getting rid of it is hard, even if not impossible. Specific architecture of biofilm created upon extracellular polymers production provides the environment not only for growth and attachment of other bacteria. The function of the EPS matrix is many-sided, including facilitating nutrient acquisition, and enhances protection against environmental stresses (Czaczyk \& Myszka, 2007).

In an effort to acquire a better understanding how bacteria behave in a biofilm and respond to environmental stresses, many protocols have been developed enabling the biofilm visualization on food processing sur- faces (Trachoo, 2003). Biofilm can grow on processing equipment surfaces such as plastic, glass, stainless steel or rubber. Stainless steel is the most commonly used material for construction of vessels, piping, valves, and various types of equipment in food industry (Arnold \& Bailay, 2000). It is indicated that hydrophobic materials are more resistant to bacterial attachment than the hydrophilic surfaces with the high surface energy and electrostatic charge such as metals (Myszka \& Czaczyk, 2011). On the other hand, it was reported that substratum hydrophobicity determines bacterial retention rather than bacterial adhesion, while bacteria adhere to almost any surface (Bos et al., 2000). Upon challenging bacterial adhesion and retention, cells interact differently to surfaces with different hydrophobicity (Myszka \& Czaczyk, 2011). Hence, cell adhesion or retention depends on the properties of the adhesion surface, type of bacterial cells, hydrodynamic conditions and surrounding environmental factors (Araújo et al., 2011; Faille et al., 2002; Fuster-Valls et al., 2008).

In this background, attention should be focused on better understanding of the interaction between different abiotic surfaces and bacterial cells in order to reduce the risk of bacterial contamination and biofilm formation. It is necessary to understand mechanisms of action of different antimicrobial agents with the potential for combating biofilms. Moreover, the emergence of resistant bacteria in biofilms clearly shows that new biofilm control strategies are required. This emphasizes also the crucial role of suitable experimental design in order to determine viability and functionality of biofilm-growing cells. This review discusses diverse microscopic approaches that can be used for bacterial biofilm studies. It is also focused on an application of antimicrobial agents for the biofilm control as well as physiological and morphological differences between biofilm cells and their free-floating counterparts.

e-mail: magdalena.olszewska@uwm.edu.pl

*Part of the results was presented at the 3-rd Workshop on Microbiology "MIKROBIOT 2013" in Łódź, Poland.

Abbreviations: EPS, extracellular polymeric substances; $C \& D$, cleaning and disinfection; hip, high-level persistence; TA, toxin-antitoxin; MDT, multidrug tolerance; SEM, scanning electron microscopy; AFM, atomic force microscopy; VBNC, viable but non-culturable; EFM, epifluorescence microscopy; CM, confocal microscopy; CLSM, confocal laser scanning microscopy; FISH, fluorescence in situ hybridization; TRITC-Con A, tetramethylrhodamine isothiocyanatelabeled lectin Concanavalin A; FITC, fluorescein isothiocyanate isomer I; DAPI, 4,6-diamidino-2-phenylindoldihydrochloride; CTC, 5-cyano-2,3-ditolyl tetrazolium chloride; PAA, peracetic acid; POA, peroctanoic acid; DVC, direct viable count; GFP, green fluorescent protein; FC, flow cytometry; pEGFP, plasmid vector red-shifted green fluorescence protein 


\section{BIOFILM FORMATION AND SIGNIFICANCE IN FOOD INDUSTRY}

Biofilm formation is a multiple-step process, involving following steps: reversible and irreversible cell attachment, biofilm maturation with cell differentiation, and cell detachment and spreading (Myszka \& Czaczyk, 2011). Bacterial biofilm formation starts with the attachment of planktonic cells to the solid surface. This reversible process with time becomes irreversible when the production of EPS proceeds and the permanent bonding to the surface occurs (Srey et al., 2013). The direct contact with a solid material is dependent upon surface appendages of bacteria including flagella, fimbriae, pili (Van Houdt \& Michiels, 2010). The process is time dependent and initiated by interactions between phenotypic features of bacteria and attachment surface such as van der Waals, electrostatic and steric forces (Myszka \& Czaczyk, 2011; Van Houdt \& Michiels, 2010). When bacteria have irreversibly adhered, the process of biofilm maturation begins. Cells are growing and dividing as well as producing extra amounts of extracellular polymers, thereby forming so-called microcolonies (Myszka \& Czaczyk, 2011). The process is slow and depends on environmental conditions and nutrients availability. Within microcolony biofilm cells accumulate quorum sensing (QS) signals causing different genetic expression to occur in those cells. QS systems appear to be involved in all steps of biofilm formation, triggering changes in the transcriptional program, considerably different from planktonic bacteria (Bai \& Rai, 2011). This phenomenon leads to phenotypic variations among biofilm cells such as metabolic gradation from fast growers to slow growers, decrease in motility of cells and changes in their respiration. What is more, biofilm cells become more resistant to antibiotics and chemicals compared to planktonic cells (Kiskó \& Szabó-Szabó, 2011; Lewis, 2005; Stewart, 2002). The bacteria in the biofilm upregulate genes involved into adaptive stress response; the bacteria are enmeshed within EPS matrix, acting like a shield partially impermeable to chemicals; biofilm cells undergo phenotypic variations as a result of microgradient in concentration of substrates and products; a small fraction of cells differentiate into highly protected persister cells - all of these concepts may be considered as biofilm resistance mechanisms (Stewart, 2002). Structurally, mature biofilm is highly organized community of microorganisms in which water channels are spread, and passages for the exchange of nutrients, metabolites and waste products are present (Kokare et al., 2009; Sauer et al., 2007; Shi \& Zhu, 2009). Functionally, the biofilm populations vary in physiological activity, according to metabolic processes and cell division. Active cells, which express high metabolic activity as well as cell division and dormant cells, which have slow metabolic processes, and no cell division exist within any bacterial population, but greater abundance of dormant cells, is evidently shown in biofilms. Dormant cells in the biofilm are therefore characterized as in persistent state responsible for antimicrobial tolerance of biofilms (Brigitte et al., 2012; Kim et al., 2009; Shah et al., 2006). Mature biofilm is a few millimeters thick and able to release the biofilm cells into the surrounding area in order to spread to other niches (Myszka \& Czaczyk, 2011)

Bacterial biofilms are problematic for many food industry branches, including dairy processing, poultry and red meat processing, brewing, fresh produce (Simões et al., 2010). Bacterial biofilm may pose a risk of food contamination and transmission of foodborne pathogens
(Lindsay \& von Holy, 2006; Shi \& Zhu, 2009). A consequence of biofilm existence may lead to food process perturbations and technological problems difficult to control (Araújo et al., 2011). Slime problems, decrease of heat transfer in heat exchangers or condensers, corrosion problems, hygienic concerns about the sanitation efficacy are common biofilm-related issues (Kiskó \& Szabó-Szabó, 2011). Bacterial biofilms are difficult to eliminate from food processing environments, what makes biofilm control a big challenge in industry (Simões et al., 2010). Cleaning and disinfection (C\&D) are extensively applied to eradicate bacterial contamination from industrial surfaces. Effectiveness of C\&D procedures are influenced by many factors, e.g. presence of organic material, $\mathrm{pH}$, temperature, water hardness, chemical inhibitors, concentration, contact time (Srey et al., 2013). When it comes to controlling biofilms, breaking-up or dissolving the EPS matrix and penetration of disinfectants through the biofilm should be considered (Kiskó \& Szabó-Szabó, 2011). There are many types of disinfectants used for sanitation in food industry including chlorine, chloramines, hydrogen peroxide, iodine, ozone, peracetic acid, quaternary ammonium compounds (Kokare et al., 2009; Srey et al., 2013). They react with various components of bacterial cells in order to exhibit the detrimental effect. Nevertheless, optimizing an effective strategy against biofilm is particularly difficult task, since agents exhibit different antimicrobial effectiveness, depending on the cells state. There is also considerable variability in susceptibilities to a certain antimicrobial concentration (Kim et al., 2008). Finally, the emergence of resistant cells within the biofilm clearly shows the need of novel approach for biofilm control. In order to select suitable antimicrobials and adjust the dosing, it is crucial to examine and compare the antimicrobials' behavior on biofilms, primarily carefully selected persister cells. The combination of several antimicrobials may be a strategy to improve biofilm control efficiency and this direction has to be comprehensively studied. In this background, attention should be focused on better understanding of the interaction between different antimicrobial agents and persisting biofilm cells. The susceptibility of these elusive cells in biofilms to antimicrobials, especially to non-antibiotic agents is not well-understood and has yet to be resolved.

\section{PERSISTERS}

Harsh environmental challenges expose existence of dormant cells with less susceptibility to stress factors. These cells are called persisters and are not mutants, neither in particular stage in the cell cycle (Lewis, 2001; Shah et al., 2006). They form a small part of bacterial populations (Leszczynska et al., 2013). Persisters are non-growing cells and known to have little metabolic activity (Shah et al., 2006). They remain dormant but are also able to re-grow after the challenge stops acting (Leszczynska et al., 2013). They are classified as significantly different from both exponentially growing and stationary cells (Shah et al., 2006). It has been shown that biofilms contain persisters tolerant to antimicrobial agents (Kim et al., 2009). The increase in tolerance concerns antibiotic as well as non-antibiotic antimicrobial agents, providing a broad spectrum defense. Nevertheless, scientists highlighted that the reduced susceptibility to antimicrobial challenges of biofilms is related to poor penetration of antimicrobial agents, phenotypic variations, multidrug efflux pumps, and presence of persisters cells (Kim et al., 2009; Stewart, 2002). The persister cells 
are reported as the major reason for antimicrobial tolerance of biofilms (Kim et al., 2009), and what is more, their occurrence in biofilms is substantial (Brigitte et al., 2012). It means that protective mechanisms in biofilms are distinct from these that are responsible for conventional antimicrobial resistance. Genes, that play an important role to this state, may include these regulating the entry to this state as well as specific defensive response.

Genes for high-level persistence (bip) have been described in Escherichia coli (Lewis, 2001; Stewart, 2002). Molecular-based data regarding $E$. coli as a model showed interesting findings about persisters. E.coli persisters exhibit overexpression of toxin-antitoxin (TA) modules. Keren et al. (2004) observed the correlation between overexpression of RelE or HipA toxins and the increase in persistence. Thus "toxins" which inhibit translation are considered as multidrug tolerance (MDT) genes. The analysis of gene expression profile revealed that persisters of $E$. coli appear surprisingly more similar to exponential, than stationary phase cells. Nevertheless, comparing to stationary and exponential cells, persisters differed significantly from both of them in upand down-regulation. The E. coli gene profile showed down-regulation of genes involved in e.g. energy production, flagellar synthesis (Shah et al., 2006). Remarkable dormancy-like genes pointed by researchers were as follows: $\operatorname{din} J$, yoeB and yefM. YoeB and YefM exist as toxins and antitoxins towards themselves and DinJ is an antitoxin towards RelE homology, YafQ. The most expressed gene was ygiU, which controls biofilm formation and together with ygiT creates TA module ygiUT, which is stated as transcriptional repressor. As TA modules can induce MDT and are highly expressed in persisters, it is suggested that the mechanism of tolerance is based on non-lethal inhibition with the binding of antimicrobials, which are prevented from killing the cell by specific MDT proteins. The case that persisters can bind antimicrobials e.g. antibiotics, but are not destroyed by them, is stated by Lewis (2010) as well, indicating reduced translation, cell wall synthesis and topoisomerase activity of dormant cells. Lately, Kim et al. (2011) established that persisters show a defective pathway involved into formation of hydroxyl radicals, one of cell death mechanisms, suggesting this phenomenon as responsible for antibiotic tolerance. Other findings concerning genes unregulated in persister cells are involved into SOS system (e.g. $\operatorname{rec} A$, umuDC, uvr $A B$, sulA) and heat and cold shock response (e.g. cspH, htrA, ibp $A B, \quad$ tp $X, c l p B)$ (Leszczynska et al., 2013). Moreover, it was suggested that persistence may be connected with the occurrence of protein aggregation and interaction upon stress, e.g. aggregates of misfolded proteins (multicomponent protein aggregates) and complexes of Dps (an example of starvation-induced protein) with DNA (Kwiatkowska et al., 2008; Leszczynska et al., 2013).

Many molecular findings have been released by now and more are expected to come about persistent state of bacteria. The recalcitrance of persister cells is now understood to be crucial in order to resolve biofilm-related problems, for food industry as well. Are disinfectant persisters and antibiotic persisters the same subset of cells? The antimicrobial tolerance need to be extensively examined in the case of treatment with different single and combined agents of all categories used in industry. Moreover, it is essential to explore the level of functionality of persisters' physiological parameters as a result of growing in the biofilm state and the antimicrobial action. These subjects are not sufficiently understood in many contexts, however, all these information may help to establish new strategies to prevent the formation of persisters and/or their elimination from food processing environments.

\section{BIOFILM STUDIES CONCERNING FOOD INDUSTRY}

The recognition of spoilage or pathogenic bacteria on food-contact surfaces as they build up and thereby form biofilms is an important area of focus towards their elimination from food processing environments. Food safety may be enhanced when the industrial materials used during processing exhibit resistance to bacterial attachment and biofilm formation. Arnold \& Bailey (2000) examined three differently finished stainless steel surfaces (sandblasted, sanded, and electropolished) for resistance to bacterial contamination from the poultry processing environment. Scanning electron microscopy (SEM) was a useful tool in calculating adhered cell counts as well as observing biofilm formation (microcolonies) on the surfaces. Whereas, atomic force microscopy (AFM) allowed examining the surface morphology, including fractal dimensions, roughness. SEM and AFM studies showed that the surface finishing treatments varies in affinity for bacteria, but improves resistance of stainless steel to bacterial attachment. The electropolished surface was less susceptible to bacterial adhesion comparing to other finishes. It was associated with the least roughness of examined surface and concluded that the smaller chemical reactivity of the surface, the weaker interactions of bacteria with it. These findings may be helpful for industry in selecting materials and finishes that are most resistant to bacterial attachment and biofilm formation. In most cases, the bacterial contaminants originate on the production line or in raw materials and exhibit resistance to environmental conditions. In this background, attention has been focused on the spoilage bacteria posing a risk of biofilm formation and resistance to different stresses in food environments. With the use of SEM Kubota et al. (2008) investigated the formation of biofilms by spoilage lactic acid bacteria and morphological changes caused by acetic acid and ethanol at single cell level. Differences in cell adherence and accumulation were observed, one formed soft- or rough-looking biofilms, others cellophane-like films. Not only biofilm surfaces were different, also the cells were altered. Comparing to planktonic cells of the same strain cell elongation was observed within the biofilm. Improved stress resistance was seen in biofilm cells, which in contrary to planktonic cells displayed no damages in membranes in the presence of $10 \%$ of acetic acid or $30 \%$ of ethanol. Additionally, it was suggested that the outer cells of the biofilms or detached cells can be damaged as a result of stress exposure. This indicates the significance of studying biofilms in the food industry, which can lead to the development of suitable diagnostic tools for controlling bacterial contaminants.

Krimmer et al. (1999) tested 16S rRNA in situ hybridization for detection and differentiation of microorganisms in biofilms. Researchers demonstrated the potential of $16 \mathrm{~S}$ rRNA-based oligonucleotide in situ hybridization for detection of biofilm-forming staphylococci and persisting bacteria of Staphylococcus aureus referred to as small-colony phenotypes. This approach is of great importance when it comes to detection of microorganisms which remain undetected by traditional methods. Direct in situ tools show that bacterial cells may remain and colonize unfavorable niches e.g. hygienic materials 
like stainless steel from which no viable cells were recovered (Brigitte et al., 2012). This emphasize the need for reliable determination of viability, a challenging task to study due to changes in physiological state of bacteria, entering dormancy state, including the viable but non-culturable (VBNC) state. Biofilm-related dormant cells are characterized by a number of molecular, structural and functional features (Zandri et al., 2012). E.g. dormant and non-culturable population simultaneously may be measured using cytological viability tests, such as fluorescence assays (Mikš-Krajnik et al., 2013; Oliver, 2005; Olszewska \& Laniewska-Trokenheim, 2013; Trachoo, 2003). Different fluorescent dyes and probes can target different structural and functional features of cells such as membrane potential, membrane integrity, enzyme activity, pump activity etc. useful for testing changes in bacterial physiology (Joux \& Lebaron, 2000). Biofilm cells grown on different surfaces can be marked with fluorescent probes/dyes and accurately evidenced with imaging object fluorescence systems like epifluorescence microscopy (EFM) and confocal microscopy (CM) (Kokare et al., 2009; Trachoo, 2003). To clarify, the EFM is based on excitation of all part of the specimen at the same time and detection of fluorescing parts together with a wide-range unfocused background. In this respect, CM techniques reflect some valuable benefits over EFM. The suitable design of confocal microscopes allows for optical sectioning, process by which three-dimensional reconstructions of complex objects are possible to observe. Further developments of CM permitted for combination of laser scanning and detection of both 3D and fluorescence objects into a technique called confocal laser scanning microscopy (CLSM). This high-resolution optical method allows scanning biofilm structure and microenvironmental conditions, e.g. $\mathrm{pH}$ gradients (Vroom et al., 1999). Microscopic tools which give the possibility to determine cell viability, cell morphology, cell arrangement and microcolony formation, are of great need for biofilm examinations. Different microscopic approaches and fluorescence assays were used so far in the variety of biofilm studies, including antimicrobial tolerance related to food industry (Table 1).

Fluorescence in situ hybridization (FISH) concentrates special interest of researchers in identification, visualization and localization of microorganisms in different fields of microbiology, including biodiversity and complexity of biofilms. FISH is usually based on the use of short RNA oligonucleotides with fluorescent molecule attached to the 3' or the 5'-end complementary to the ribosomal RNA sequence of cells. The probes target a specific sequence of rRNA in the intact cells and with the application of CLSM it is possible not only to identify microorganisms but also to explore their location in a three-dimensional community. Besides, FISH and 16-23S rRNA hybridization can be applied to observe decrease in the viability of cells as the biofilm ages (Kokare et al., 2009). FISH can be used extensively in biofilm studies (Moter \& Göbel, 2000), enabling investigators to map complex microbial communities e.g. on hydrophobic and hydrophilic surfaces (Araujo et al., 2004), on pipes from water supply networks (Juhna et al., 2007), and on food processing surfaces (Bagge et al., 2001).

Other scientific data demontrate following potentials of apllying fluorescent assays. The availability of fluorescenct dyes such as TRITC-Con A (tetramethylrhodamine isothiocyanate-labeled lectin Concanavalin A), FITC (fluorescein isothiocyanate isomer I) and DAPI (4,6-diamidino-2-phenylindoldihydrochloride) let Nosyk et al. (2008) accurately visualize and compare the struc- ture and composition of the EPS of biofilms by staining following components: proteins, carbohydrates, DNA. The EFM was successfully applied for composition of different biofilm flocs such as nitrifying activated sludge from a municipal wartewater treatment plant and pure cultures of Pseudomonas putida ATCC 17514. Wirtanen et al. (2001) studied the effect of antimicrobial activities of disinfectants on Pseudomonas aeruginosa and Pseudomonas fragi biofilm by the use of EFM. Commercially used in food industry disinfectants were tested: alcohol-based, tenside-based, peroxide-based and chlorine-based products. Conventional and microscopic methods were compared by monitoring levels of enumerated cells after the disinfectant exposure. EFM based on metabolic indicator system CTC (5-cyano-2,3-ditolyl tetrazolium chloride)/ DAPI results showed the great extent of respiring cells after alcohol-based challenge, contrary to cultivation methods, which had indicated antimicrobial effectiveness of this type of disinfectant. It suggests that for some antimicrobial agents inhibition of the bacterial population may occur without destroying the cells. The careful attention to the choice of methods and combination of different tools is then required to predict and evaluate the efficacy of disinfectants against biofilm bacteria. What is more, survival of a foodborne pathogen Campylobacter jejuni in biofilms was examined after treatment with sanitizers including chlorine, quaternary ammonia, peracetic acid (PAA), and a PAA/peroctanoic acid mixture (PAA/POA) (Trachoo \& Frank, 2002). The antimicrobial effectiveness of sanitizers against $C$. jejuni in the biofilm was weakened. C. jejuni in the biofilm was completely inactivated in presence of chlorine and susceptible to other sanitizers, but without entire inactivation. Further experiments of the viability of $C$. jejuni in biofilms with a cultural method and direct viable count (DVC) revealed that the number of viable C. jejuni determined by DVC was greater than that determined by the cultural method, indicating that $C$. jejuni may form a VBNC state within the biofilm. Both methods indicated that existence in the biofilm enhance the survival of C. jejuni (Trachoo et al., 2002). A similar approach with the use of direct EFM and plate counts, were used to monitor the effect of slow and rapid air-drying on Enterobacter cloacae, Pseudomonas aeruginosa, Staphylococcus aureus survival on stainless steel surfaces. Different abilities to adhere and survive stress conditions were observed among strains. What is worth underlining, bacteria on the surface and exposed to adverse conditions were not obtained by cultivation, but they still presented viability and potential danger (Fuster-Valls et al., 2008).

The examination of planktonic and biofilm cells to antimicrobial agents such as widely used for controlling biofilms chlorine, silver ions and tobramycin was conducted by Kim at al. (2008). Three methods of assessment were used to compare the antimicrobial effects: plate counts and CTC staining as well as BacLight ${ }^{\circledR}$ Live/Dead staining along with CLSM and EFM. It has been confirmed that biofilm cells are significantly more tolerant to antimicrobials than planktonic cells. After antimicrobial treatments of biofilms, many cells retained respiratory activity or membrane integrity, but lost the culturability. Based on CTC staining, the respiratory activity of biofilm cells was significantly decreased as a result of the antibiotic action, but the membrane activity targeted by Live/Dead staining was sustained especially when compared to the level of cells after chlorine- and silver-treatment. Chorine and silver ions triggered damages in the cell membrane, while tobramycin most effectively affected respiratory activity. The treatment with sil- 


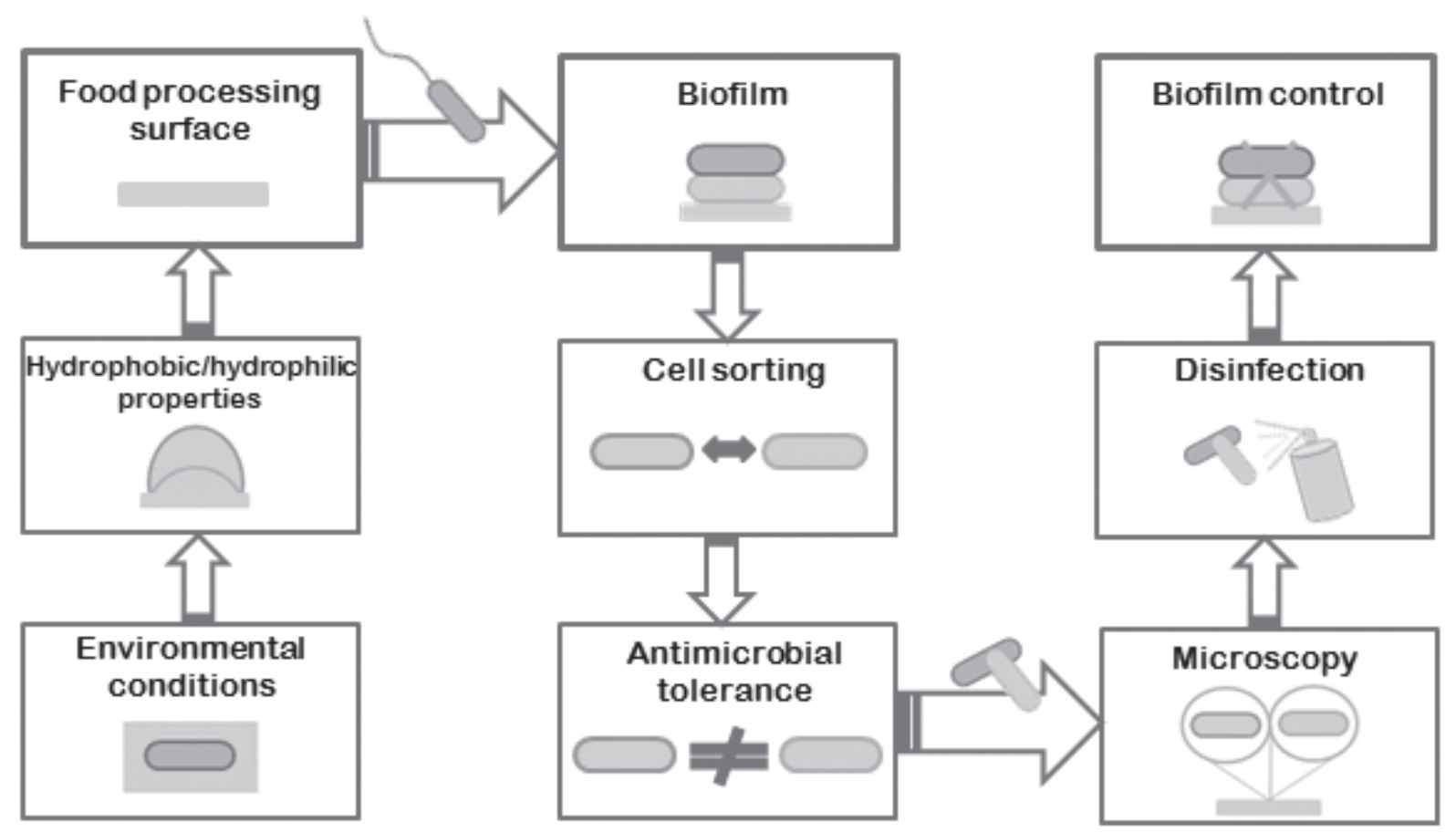

Figure 1. The most essential aspects of the biofilm related studies.

ver and tobramycin in combination was the most effective for biofilm control. However, chlorine was less effective in combination with antibiotics, possibly because of reaction between chlorine and antibiotics decreasing available concentrations of antimicrobials.

Furthermore, bacterial cells can be fluorescently detected without fluorescent staining through the plasmid for green fluorescent protein (GFP) as a indicator of bacterial protein synthesis. Many interesting study models can be developed with the use of GFP and available fluorescence tools. E.g. Kim et al. (2009) used flow cytometry (FC) to sort active and dormant cells of Pseudomonas aeruginosa biofilm, and then tested tolerance to antimicrobial agents such as chlorine, hydrogen peroxide, silver ions and antibiotics. It was observed that active cells compared with dormant cells in the biofilm are bigger in size and exhibit higher intracellular density. Differences in cell physiology according to the level of protein synthesis revealed differences in tolerance towards antimicrobials. Dormant cells were more tolerant to the antibiotic and silver ions and active cells to chlorine. Dormant cells were significantly inactivated by chlorine, which performed higher effectivity under anaerobic conditions. So, antimicrobials may exert different effects on dormant and active cells in biofilms depending on their antimicrobial action and environmental conditions (Kim et al., 2009). Besides that, E. coli O157:H7 transffered with a plasmid vector red-shifted green fluorescence protein ( $p E G F P$ ) was studied according to abitily of this pathogenic bacterium to attach to produces (Takeuchi \& Frank, 2001a). The application of EGFP as a marker for E. coli O157:H7 on green leaf lettuce, cauliflower, and tomato was evaluated using CLSM and compared with results obtained by immunostaining. Based on these techniques, it was concluded that EGFP can be used as a marker to identify attachment of E. coli $\mathrm{O} 157: \mathrm{H} 7$ on lettuce and cauliflower but may not be appropriate on tomato. Other findings demonstrated the possibility of E. coli $\mathrm{O} 157: \mathrm{H} 7$ to penetrate into lettuce tissues and the effect of chlorine treatment on cell viability (Takeuchi \& Frank, 2000). E. coli O157:H7 attached favorably to cut edges than the surface of lettuce leaves. E. coli O157:H7 cells penetrated into lettuce leaves from cut edges what was observed with the immunostaining using a FITC-labeled antibody. The chlorine treatment affected significantly the cell attachment, but the reduction of cell population did not exceed level below $8 \log \mathrm{CFU} / \mathrm{cm}^{2}$. Other studies concerning the attachment of E. coli O157:H7 and Listeria monocytogenes, Salmonella Typhimurium, Pseudomonas fluorescens on iceberg lettuce showed that different species attached differently to lettuce structures (Takeuchi et al., 2000). In addition, some of them were located within the lettuce tissues, confirming their abilities to stay viable and penetrate from the cut edge surface, additionally one of the tested strains, P. fluorescens was able to form microcolonies. Based on these findings, it was proven that determination of bacterial viability directly from foods is a desirable approach in understanding bacterial adhesion process (Takeuchi \& Frank, 2001b).

Moreover, hyperspectral fluorescence imaging system techniques were recently developed as potential tools for quality and safety assessments of food products. Hyperspectral imaging system is capable of reflectance and fluorescence measurements for creation of two-dimensional spatial and spectral images of relatively large surface areas. With the help of fluorescence imaging methods surfaces such as food processing equipment can be scanned for bacterial contamination. Jun et al. (2008) detected E. coli $\mathrm{O} 157: \mathrm{H7}$, E. coli, Pseudomonas pertucinogena, Erwinia chrsanthemi, Listeria innocua biofilm on stainless steel with the use of a portable hyperspectral fluorescence imaging system. This approach can support inspections for biofilm contamination occurring on equipment in areas where nutrients can build up and cleaning agents cannot effectively access. Further investigations let to distinguish morphological differences in biofilm formation between E. coli and Salmonella. E. coli formed granular aggregates on stainless steel and Salmonella occurred in a form of 
Table 1. Diverse diagnostic approaches used for biofilm studies in food industry.

\begin{tabular}{|c|c|c|c|}
\hline Method & Application & Strain & Reference \\
\hline \multirow{2}{*}{$\begin{array}{l}\text { Scanning electron microscopy } \\
\text { (SEM) }\end{array}$} & $\begin{array}{l}\text { Resistance of stainless steel to bacterial } \\
\text { attachment and biofilm formation }\end{array}$ & $\begin{array}{l}\text { Bacterial populations from } \\
\text { the poultry processing } \\
\text { environment }\end{array}$ & Arnold \& Bailay (2000) \\
\hline & $\begin{array}{l}\text { Formation of biofilms by lactic acid bac- } \\
\text { teria causing food deterioration or conta- } \\
\text { mination }\end{array}$ & $\begin{array}{l}\text { Lactobacillus plantarum } \\
\text { Lactobacillus brevis } \\
\text { Lactobacillus fructivorans }\end{array}$ & Kubota et al. (2008) \\
\hline $\begin{array}{l}\text { Epifluorescence microscopy / } \\
\text { rRNA oligonucleotides }\end{array}$ & $\begin{array}{l}\text { Adhesion and differentiation of the fish } \\
\text { spoilage bacterium on food processing } \\
\text { surfaces }\end{array}$ & Shewanella putrefaciens & Bagge et al. (2001) \\
\hline $\begin{array}{l}\text { Epifluorescence microscopy / } \\
\text { FITC, TRITC-ConA, DAPI }\end{array}$ & $\begin{array}{l}\text { Visualization and comparison of the } \\
\text { structure and composition of the EPS of } \\
\text { biofilms }\end{array}$ & $\begin{array}{l}\text { biofilm flocs: nitrifying } \\
\text { activated sludge Pseudo- } \\
\text { monas putida }\end{array}$ & Nosyk et al. (2008) \\
\hline $\begin{array}{l}\text { Epifluorescence microscopy / } \\
\text { CTC+DAPI }\end{array}$ & $\begin{array}{l}\text { Evaluation of the antimicrobial activities } \\
\text { of disinfectants on Pseudomonas spp. } \\
\text { biofilm }\end{array}$ & $\begin{array}{l}\text { Pseudomonas aeruginosa } \\
\text { Pseudomonas fragi }\end{array}$ & Wirtanen et al. (2001) \\
\hline $\begin{array}{l}\text { Confocal laser scanning microsco- } \\
\text { py / FITC }\end{array}$ & $\begin{array}{l}\text { Visualization of bacterial attachment on } \\
\text { iceberg lettuce }\end{array}$ & $\begin{array}{l}\text { Escherichia coli O157:H7 } \\
\text { Listeria monocytogenes } \\
\text { Salmonella Typhimurium } \\
\text { Pseudomonas fluorescens }\end{array}$ & Takeuchi et al. (2000) \\
\hline $\begin{array}{l}\text { Epifluorescence microscopy / } \\
\text { Live/Dead }{ }^{\circ} \text { Viability Kit }\end{array}$ & $\begin{array}{l}\text { The effect of different environmental } \\
\text { conditions e.g. slow and rapid air-drying } \\
\text { on the bacterial survival on stainless steel } \\
\text { surfaces }\end{array}$ & $\begin{array}{l}\text { Enterobacter cloacae, } \\
\text { Pseudomonas aeruginosa } \\
\text { Staphylococcus aureus }\end{array}$ & Fuster-Valls et al. (2008) \\
\hline $\begin{array}{l}\text { Epifluorescence microscopy } \\
\text { Confocal laser scanning microsco- } \\
\text { py / CTC \& BacLight Live/Dead }{ }^{\circ} \\
\text { staining }\end{array}$ & $\begin{array}{l}\text { Examination of antimicrobials activities } \\
\text { such as chlorine, silver, tobramycin on } \\
\text { biofilms }\end{array}$ & Pseudomonas aeruginosa & Kim et al. (2008) \\
\hline $\begin{array}{l}\text { Flow cytometry / } \\
\text { green fluorescent protein (GFP) }\end{array}$ & $\begin{array}{l}\text { Sorting of active and dormant cells from } \\
\text { bacterial biofilm as well as antimicrobial } \\
\text { tolerance }\end{array}$ & Pseudomonas aeruginosa & Kim et al. (2009) \\
\hline $\begin{array}{l}\text { Confocal scanning laser micro- } \\
\text { scopy / } \\
\text { red-shifted green fluorescence } \\
\text { protein (pEGFP) / } \\
\text { immunostaining }\end{array}$ & $\begin{array}{l}\text { Attachment of pathogenic bacteria to } \\
\text { produces }\end{array}$ & Escherichia coli O157:H7 & $\begin{array}{l}\text { Takeuchi \& Frank (2001a) } \\
\text { Takeuchi \& Frank (2000) }\end{array}$ \\
\hline \multirow{3}{*}{$\begin{array}{l}\text { Hyperspectral fluorescence imag- } \\
\text { ing system using electron-multi- } \\
\text { playing charge-coupled-device }\end{array}$} & $\begin{array}{l}\text { Detection of microbial biofilm on stainless } \\
\text { steel }\end{array}$ & $\begin{array}{l}\text { Escherichia coli } 0157: \mathrm{H} 7 \\
\text { Escherichia coli } \\
\text { Pseudomonas pertucino- } \\
\text { gena } \\
\text { Erwinia chrsanthemi } \\
\text { Listeria innocua } \\
\text { Salmonella Typhimurium }\end{array}$ & $\begin{array}{l}\text { Jun et al. (2008) } \\
\text { Jun et al. (2009) }\end{array}$ \\
\hline & $\begin{array}{l}\text { Detection of fecal matter on lettuce and } \\
\text { spinach leaves }\end{array}$ & & Kang et al. (2011) \\
\hline & $\begin{array}{l}\text { Detection of organic matter on poultry } \\
\text { processing plant equipment surfaces }\end{array}$ & & Cho et al. (2007) \\
\hline
\end{tabular}

dense biofilm (pellicles) (Jun et al., 2009). Other findings with the use of a potentially biosensor-based technique addressed the feasibility for the detection of organic residues, specifically fecal matter on fresh produce e.g. green leafy vegetables (Kang et al., 2011) and processing plant equipment surfaces e.g. from meat and poultry industry (Cho et al., 2007). Altogether, it was shown that hyperspecrtal imaging techniques can be used for sanitation monitoring of food processing equipment surfaces as well as raw materials for food.

\section{CONCLUSIONS}

Bacterial biofilms are now commonly recognized as problematic for food industry. Recent years have showed that the scientific interest in biofilms has undoubtedly elevated bringing valuable information about the switch to the biofilm mode of existence. The more we learn about the biofilm formation, the more we understand about the forces that drive the switch to the biofilm-growing state. E.g. one of the research directions have led to persister cells, which increase the capacity of biofilms to survive stresses.

Certainly, microscopic techniques can be incorporated in most of experimental conditions concerning biofilms. Microscopic approaches are very useful not just to the biofilm formation, but to the efficacy of antimicrobials against biofilms too. The understanding of bacterial attachment and factors which influence this process to solid surfaces, such as stainless steel, may help in the development of surfaces with reduced attachment for cells. The development of effective sanitation procedures, thus reducing the potential contamination of foods, can be also achieved. Microscopic techniques can also allow 
locating viable cells in respect to different physiological functions within a food tissue, in order to assess the risk of food contamination and indicate factors which influence bacterial attachment to produces. Finally, further development of these techniques can support inspections for biofilm contaminants occurring on food processing surfaces in order to ensure food quality and safety. In summary, the graphical representation in Fig. 1 may be a possible way leading through biofilm case-by-case studies influencing systematic understanding of the biofilm mode of existence.

\section{REFERENCES}

Araujo JC, Mortara R, Campos JR, Vazoller RF (2004) Development and analysis of anaerobic biofilms onto hydrophobic and hydrophilic surfaces. Environ Tech 25: 809-817.

Araújo P, Lemos M, Mergulhão F, Melo L, Simões M (2011) Antimicrobial resistance to disinfectants in biofilms. Science against microbial pathogens - communicating current research and technological advances. Méndez-Vilas A, ed, pp 826-834. Formatex Research Center, Badajoz, Spain.

Arnold JW, Bailey GW (2000) Surface finishes on stainless steel reduce bacterial attachment and early biofilm formation: scanning electron and atomic force microscopy study. Poultry Sci 79: 1839-1845.

Bagge D, Hjelm M, Johansen C, Huber I, Gram L (2001) Shewanella putrefaciens adhesion and biofilm formation on food processing surfaces. Appl Environ Microbiol 67: 2319-2325.

Bai AJ, Rai VR (2011) Bacterial quorum sensing and food industry. Compr Rev Food Sci F 10: 183-193.

Bos R, van der Mei HC, Gold J, Busscher HJ (2000) Retention of bacteria on a substratum surface with micro-patterned hydrophobicity. FEMS Microbiol Lett 189: 311-315.

Brigitte C, Elissa K, Olivier F, Souad C (2012) Bacterial persistence and transient survival on open surface. JHED 1: 54-56.

Cho B-K, Chen Y-R, Kim MS (2007) Multispectral detection of organic residues on poultry processing plant equipment based on hyperspectral reflectance imaging technique. Comput Electron Agr 57: 177-189.

Czaczyk K, Myszka K (2007) Biosynthesis of extracellular polymeric substances (EPS) and its role in microbial biofilm formation. Polish J Environ Stud 16: 799-806.

Faille C, Jullien C, Fontaine F, Bellon-Fontaine MN, Slomianny C, Benezech T (2002) Adhesion of Bacillus spores and Escherichia coli cells to inert surfaces: role of surface hydrophobicity. Can J Microbiol 48: $728-38$

Fuster-Valls N, Hernández-Herrero M, Marín-de-Mateo M, RodríguezJerez JJ (2008) Effect of different environmental conditions on the bacteria survival on stainless steel surfaces. Food Control 19: 308-314.

Giaouris E, Chorianopoulos N, Skandamis P, Nychas G-J (2012) Attachment and biofilm rormation by Salmonella in food processing environments, In Salmonella - A Dangerous Foodborne Pathogen. Barakat S M Mahmoud ed, pp 157-180. InTech, Rijeka, Croatia.

Joux F, Lebaron F (2000) Use of fluorescent probes to assess physiological functions of bacteria at single-cell level. Microbes Infection 2: 1523-1535.

Juhna T, Birzniece D, Larsson S, Zulenkovs D, Sharipo A, Azevedo NF, Ménard-Szczebara F, Castagnet S, Féliers C, Keevil CW (2007) Detection of Escherichia coli in biofilms from pipe samples and coupons in drinking water distribution networks. Appl Environ Microbiol 73: 7456-7464.

Jun W, Kim MS, Lee K, Millner P, Chao K (2009) Assessment of bacterial biofilm on stainless steel by hyperspectral fluorescence imaging. Sens \& Instrumen Food Qual 3: 41-48.

Jun W, Lee K, Millner P, Sharma M, Chao K, Kim MS (2008) Detection of bacterial biofilm on stainless steel by hyperspectral fluorescence imaging. Food Processing Automation Conference: 701P0508cd.

Kang S, Lee K, Son J, Kim MS (2011) Detection of fecal contamination on leafy greens by hyperspectral imaging. Procedia Food Sci 1: 953-959.

Keren I, Shah D, Spoering A, Kaldalu N, Lewis K (2004) Specialized persister cells and mechanism of multidrug tolerance in E. coli. $J$ Bacteriol 186: 8172-8180.

Kim J, Hahn JS, Franklin MJ, Stewart PS, Yoon J (2009) Tolerance of dormant and active cells in Pseudomonas aeruginosa PA01 biofilm to antimicrobial agents. I Antimicrob Chemother 63: 129-35.

Kim J, Pitts B, Stewart PS, Camper A, Yoon J (2008) Comparison of the antimicrobial effects of chlorine, silver ion, and tobramycin on biofilm. Antimicrob Agents Chemother 52: 1446-1453.

Kim JS, Heo P, Yang TJ, Lee KS, Jin YS, Kim SK, Shin D, Kweon DH (2011) Bacterial persisters tolerate antibiotics by not producing hydroxyl radicals. Biochem Biophys Res Commun 413: 105-110.
Kiskó G, Szabó-Szabó O (2011) Biofilm removal of Pseudomonas strains using hot water sanitation. Acta Univ Sapientiae, Alimentaria 4: 69-79. Kokare CR, Chakraborty S, Khopade AN, Mahadik KR (2009) Biofilm: importance and applications. Ind J Biotech 8: 159-168.

Krimmer V, Merkert H, von Eiff C, Frosch M, Eulert J, Löhr JF, Hacker J, Ziebuhr W (1999) Detection of Staphylococcus aureus and Staphylococcus epidermidis in clinical samples by $16 \mathrm{~S}$ rRNA-directed in situ hybridization. I Clin Microbiol 37: 2667-2673.

Kubota H, Senda S, Nomura N, Tokuda H, Uchiyama H (2008) Biofilm formation by lactic acid bacteria and resistance to environmental stress. J Biosci Bioeng 106: 381-386.

Kwiatkowska J, Matuszewska E, Kuczynska-Wisnik D, Laskowska E (2008) Aggregation of Escherichia coli proteins during stationary phase depends on glucose and oxygen availability. Res Microbiol 159: 651-657.

Leszczynska D, Matuszewska E, Kuczynska-Wisnik D, FurmanekBlaszk B, Laskowska E (2013) The formation of persister cells in stationary-phase cultures of Escherichia coli is associated with the aggregation of endogenous proteins. PLOS ONE 8: e54737.

Lewis K (2001) Riddle of biofilm resistance. Antimicrob Agents Chemother 45: 999-1007.

Lewis K (2010) Persister cells. Annu Rev Microbiol 64: 357-372.

Lewis K (2005) Persister cells and the riddle of biofilm survival. Biochemistry (Mosc.) 70: 267-274.

Lindsay D, von Holy A (2006) What food safety professionals should know about bacterial biofilms. British Food J 108: 27-37.

Mikš-Krajnik M, Babuchowski A, Białobrzewski I (2013) Impact of physiological state of starter culture on ripening and flavour development of Swiss-Dutch-type cheese. Int J Dairy Tech 66: 562-569.

Moter A, Göbel UB (2000) Fluorescence in situ hybridization for direct visualization of microorganisms. J Microbiol Met 41: 85-112.

Myszka K, Czaczyk K (2011) Bacterial biofilms on food contact surfaces - a review. Pol J Food Nutr Sci 61: 173-180.

Nosyk O, Haseborg E, Metzger U, Frimmel FH (2008) A standardized pre-treatment method of biofilm flocs for fluorescence microscopic characterization. J Microbiol Met 75: 449-456.

Oliver JD (2005) The viable but nonculturable state in bacteria. J Microbiol 43: 93-100.

Olszewska M, Laniewska-Trokenheim $\ell$ (2013) Responses of lactic acid bacteria to stress - VBNC state. Zymnosc Nauka Technologia Jakosc 90: 15-28.

Shah D, Zhang Z, Khodursky A, Kaldalu N, Kurg K, Lewis K (2006) Persisters: a distinct physiological state of E. coli. BMC Microbiol 6: 1471-2180.

Shi X, Zhu X (2009) Biofilm formation and food safety in food industries. Trends Food Sci Tech 20: 407-413.

Simões M, Simões LC, Vieira MJ (2010) A review of current and emergent biofilm control strategies. LWT-Food Sci Technol 43: 573-583.

Srey S, Jahid IK, Ha S-D (2013) Biofilm formation in food industries: a food safety concern. Food Control 31: 572-585.

Stewart PS (2002) Mechanisms of antibiotic resistance in bacterial biofilms. Int J Microbiol 292: 107-113.

Takeuchi K, Frank JF (2000) Penetration of Escherichia coli O157:H7 into lettuce tissues as affected by inoculum size and temperature and the effect of chlorine treatment on cell viability. J Food Prot 63: $434-440$.

Takeuchi K, Frank JF (2001a) Expression of red-shifted green fluorescent protein by Escherichia coli $\mathrm{O} 157: \mathrm{H} 7$ as a marker for the detection of cells on fresh produce. J Food Prot 64: 298-304.

Takeuchi K, Frank JF (2001b) Confocal microscopy and microbial viability detection for food research. J Food Prot 64: 2088-2102.

Takeuchi K, Matute CM, Hassan AN, Frank JF (2000) Comparison of the attachment of Escherichia coli O157:H7, Listeria monocytogenes, Salmonella Typhimurium, and Pseudomonas fuorescens to lettuce leaves. J Food Prot 63: 1433-1437.

Trachoo N (2003) Biofilms and the food industry. Songklanakarin J Sci Technol 25: 807-815.

Trachoo N, Frank JF (2002) Effectiveness of chemical sanitizers against Campylobacter jejuni-containing biofilms. J Food Prot 65: 11171121.

Trachoo N, Frank JF, Stern NJ (2002) Survival of Campylobacter jejuni in biofilms isolated from chicken houses. J Food Prot 65: 1110-1116.

Van Houdt R, Michiels CW (2010) Biofilm formation and the food industry, a focus on the bacterial outer surface. J Appl Microbiol 109: 1117-1131.

Vroom JM, DeGrauw KJ, Gerritsen HC, Bradshaw DJ, Marsh PD, Watson GK, Birmingham JJ, Allison C (1999) Depth penetration and detection of $\mathrm{pH}$ gradients in biofilms by two-photon excitation microscopy. Appl Environ Microbiol 65: 3502-3511.

Wirtanen G, Salo S, Helander IM, Mattila-Sandholm T (2001) Microbiological methods for testing disinfectant efficiency on Pseudomonas biofilm. Colloids Surf B 20: 37-50.

Zandri G, Pasquaroli S, Vignaroli C, Talevi S, Manso E, Donelli G, Biavasco F (2012) Detection of viable but non-culturable staphylococci in biofilms from central venous catheters negative on standard microbiological assays. Clin Microbiol Infec 18: E259-E261. 